\title{
PENDAMPINGAN UMKM PERCETAKAN PAVING HIDROLIS PADA UD RINA KHATULISTIWA DESA PAGERHARJO KECAMATAN WEDARIJAKSA KABUPATEN PATI
}

\author{
Nanik Ermawati ${ }^{1}$, Nurul Rizka Arumsari ${ }^{2}$, Rangga Primadasa $^{3}$ \\ ${ }^{1,2}$ Fakultas Ekonomi \& Bisnis, ${ }^{3}$ Fakultas Teknik Universitas Muria Kudus \\ nanik.ermawati@umk.ac.id
}

\begin{abstract}
Abstrak
UMKM percetakan paving hidrolis UD Rina Khatulistiwa dimiliki oleh H Sayogo di Kabupaten Pati. Usaha ini didirikan semenjak 10 tahun yang lalu dan saat ini mengalami perkembangan usaha yang bagus. Produksi paving ini menggunakan mesin hidrolis. Setiap bulan mampu menjual paving 1000 meter. Namun untuk kualitas paving sendiri kadang paving dapat pecah. Sehingga konsumen bisa saja pindah ke toko yang lain, hal ini menurunkan omzet usaha ini. Dari sisi keuangan UMKM ini belum melakukan perhitungan laba rugi secara bulanan. Berdasarkan beberapa permasalahan yang dihadapi oleh mitra tersebut maka kami memberikan solusi atas permasalahan tersebut dengan cara : 1). Pelatihan peningkatan kualitas paving dengan melakukan kegiatan perbaikan pada pekerja, metode, material, dan mesin. 2). Pelatihan penyusunan laporan keuangan, 3). Pelatihan peningkatan penjualan melalui pemasaran online. Tujuan dari program pelatihan ini supaya UMKM mampu meningkatkan produktivitas dan penjualan produknya. Dengan meningkatnya penjualan produk paving ini akan meningkatkan kesejahteraan UMKM dan kesejahteraan karyawan UMKM. Sehingga kesejahteraan masyarakat juga ikut meningkat. Hasil pendampingan UMKM ini diharapkan 1). Produk paving yang berkualitas, 2). Karyawan UD Rina Khatulistiwa mampu menyusun laporan keuangan, 3). Karyawan mampu memasarkan produk secara online
\end{abstract}

Kata kunci : paving, laporan keuangan, kualitas produk, pemasaran online

\section{Pendahuluan}

Produk paving saat ini menjadi produk yang banyak dicari masyarakat. Produk ini dapat digunakan untuk membuat jalan, membuat taman, mempercantik halaman rumah, mengatasi kawasan yang kumuh (Adibroto, 2014). Apalagi di musim penghujan, keadaan lingkungan akan menjadi becek sehingga sangat mengganggu aktivitas. Dengan adanya produk paving ini jalanan akan menjadi lebih bersih. Jalan akan menjadi lebih rapi. Paving ini sangat digemari oleh masyarakat karena kegunaannya yang dapat membuat lingkungan menjadi bagus. Setiap rumah sekarang pasti membutuhkan paving. Paving ini memiliki umur ekonomis yang lama bisa sampai 3 tahun (Adibroto, 2014). Umur ekonomis paving ini dapat dilihat dari jenis kualitas produk. Kualitas produk paving ini juga dapat dilihat dari bagaimana proses memproduksinya. Proses memproduksi paving ini dapat menggunakan geblok tangan maupun mesin hidrolis . Untuk mendapatkan kualitas yang bagus proses produksi dengan menggunakan mesin hidrolis.

Selain proses produksi kualitas paving ini juga dapat dilihat dari bagaimana komposisi dari adonan paving sendiri (Sembiring \& Saruksuk, 2018). Dengan menggunakan komposisi yang pas akan menghasilkan paving yang berkualitas. Paving yang berkualitas ini akan di cari oleh banyak masyarakat. Namun paving yang berkualitas juga memiliki harga jual yang lumayan juga. Di Kabupaten Pati sendiri tingkat kebutuhan paving juga lumayan banyak. Hal ini di dukung dengan banyaknya perumahan baru yang mulai di didirikan. Kebanyakan perumahan baru ini membutuhkan produk paving untuk membangun jalanan rumah, halaman rumah maupun jalanan setapak. Salah satu produsen paving di Kabupaten pati ini adalah UMKM UD Rina Khatulistiwa. Berikut ini adalah bahan dan proses untuk membuat paving : Pasir trash 8 timba, Abu batu 4 timba, Pasir muntilan 1 timba, Semen 1 timba, Air secukupnya. Cara membuat : 1. Bahan pasir trash, abu batu, pasir muntilan, semen, air di aduk ke dalam molen. 2. Adonan dimasukkan ke dalam mesin pencetak paving. 3. Paving yang sudah di cetak di tata rapi di tempat nya. 4 . 
Sore hari paving di siram dengan air. 5. Paving siap untuk dipindahkan ke tempat yang sudah disediakan. 6. 1 zak semen $50 \mathrm{~kg}$ menjadi 180 paving segi 6 ukuran $5 \mathrm{~cm}$ (Sembiring \& Saruksuk, 2018).

Berdasarkan hasil observasi kami di lapangan, UMKM ini memiliki potensi penjualan yang lumayan bagus. Hal ini dikarenakan banyak pelanggan yang sudah menjadi mitra UMKM untuk membeli paving ini. Namun pelanggan ini ada beberapa yang memberikan komplain dari kualitas paving ini. Hal ini dikarenakan produk pavingnya ada beberapa yang pecah. Berikut ini gambar produk paving yang di hasilkan oleh UMKM :

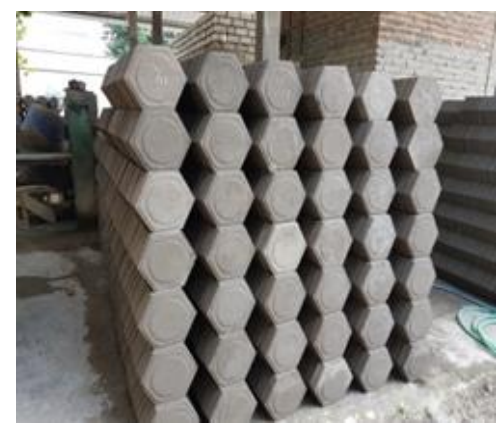

Gambar 1. Produk paving

Produk paving ini di lihat dari bentuknya sudah bagus, namun untuk kualitas memang belum bisa menjadi kualitas yang bagus karena ada beberapa yang dapat pecah. Kemungkinan pecahnya ini dari proses pembuatan paving yang menggunakan mesin yang memang di rancang sendiri dengan mesin hidrolis. Berikut ini gambar mesin dan teknologi yang digunakan oleh UMKM :

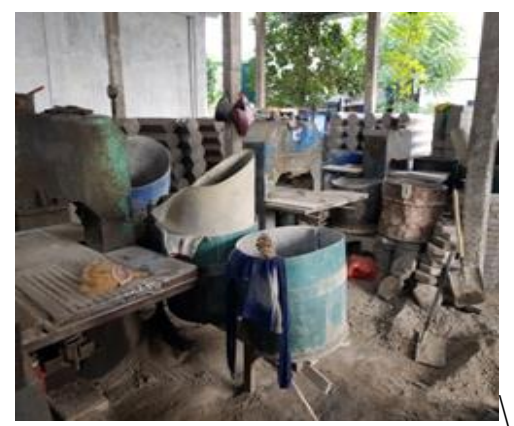

Gambar 2. Mesin \& Teknologi Paving

Berdasarkan hasil penelusuran di lapangan mesin dan teknologi yang digunakan oleh UMKM hanya menggunakan mesin yang sederhana. Alat yang digunakan untuk memproduksi paving juga menggunakan alat yang sederhana.

UMKM Rina Khatulistiwa ini berdiri sejak tahun 2009. UMKM ini bergerak dibidang percetakan paving. Awal pendirian usaha ini percetakan paving menggunakan model paving geblok. Paving geblok adalah model percetakan paving dengan cara di press dengan alat cetak menggunakan tenaga tangan manusia. Sampai dengan tahun 2019, UMKM ini mengalami kenaikan omzet paving. Berikut ini data \% kenaikan omzet paving dari tahun 2015 sampai dengan tahun 2019 :

Tabel 1.Kenaikan Omzet Paving 2015-2019

\begin{tabular}{ll}
\hline Tahun & Omzet \\
\hline 2019 & $15 \%$ \\
2018 & $13 \%$ \\
2017 & $7 \%$ \\
2016 & $5 \%$ \\
2015 & $5 \%$ \\
\hline
\end{tabular}

Dengan adanya kenaikan omzet paving ini, UMKM beralih teknologi dengan menggunakan mesin hidrolis. Dengan harapan menggunakan mesin hidrolis ini dapat memproduksi paving dengan jumlah yang lumayan banyak dalam sehari. Seiring dengan berjalannya usaha ini, banyak konsumen dari toko bangunan lain yang membeli produk paving ini. Berikut ini daftar toko bangunan yang mulai membeli paving produk ini : 


\begin{tabular}{ll}
\multicolumn{2}{c}{ Tabel 2 : Daftar Pelanggan } \\
\hline No & Nama Toko \\
\hline 1 & Toko Barokah \\
2 & UD Adi Jaya \\
3 & UD Handayani \\
4 & UD Narti \\
5 & UD Kawan Mitra \\
\hline
\end{tabular}

Berdasarkan data konsumen tersebut, UMKM ini makin bagus perkembangan usahanya. Namun di tengah perjalanan usaha ini, UMKM ini masih belum bisa menentukan komposisi atau takaran paving yang pas seperti apa, sehingga kualitas produk paving ini menjadi lebih unggul. Selama ini UMKM memproduksi paving dengan pengetahuan yang seadanya. Untuk membuat komposisi paving ini, UMKM belum memiliki standar yang sesuai dengan Standar Nasional Indonesia (SNI). UMKM ini masih membutuhkan banyak masukan untuk dapat memproduksi paving dengan kualitas yang bagus. Seperti diketahui bahwa paving yang diproduksi oleh UD Rina Khatulistiwa sebenarnya memiliki campuran seperti paving pada umumnya yaitu semen, pasir, batu, dan air. Namun demikian kualitasnya oleh konsumen kurang disukai, dikarenakan mudah pecah. Untuk menyelesaikan permasalahan tersebut, langkah pertama yang dilakukan adalah mengidentifikasi penyebab dari kualitas paving hasil produksi UD Rina Khatulistiwa jelek. Berikut ini permasalahan yang dihadapi oleh UD Rina Khatulistiwa :

\section{a. Bidang Produksi}

Dalam bidang produksi yang dihadapi UD Rina Khatulistiwa adalah kualitas produk paving. Kualitas produk paving ini lemah sehingga perlu dicari kelemahan produk ini. Diagram Ishikawa digunakan sebagai alat dalam proses identifikasi ini, dimana sebab-akibat permasalahan digambarkan dengan jelas (Corviniensis et al., 2014). Hasil identifikasi permasalahan tersebut adalah sebagai berikut :

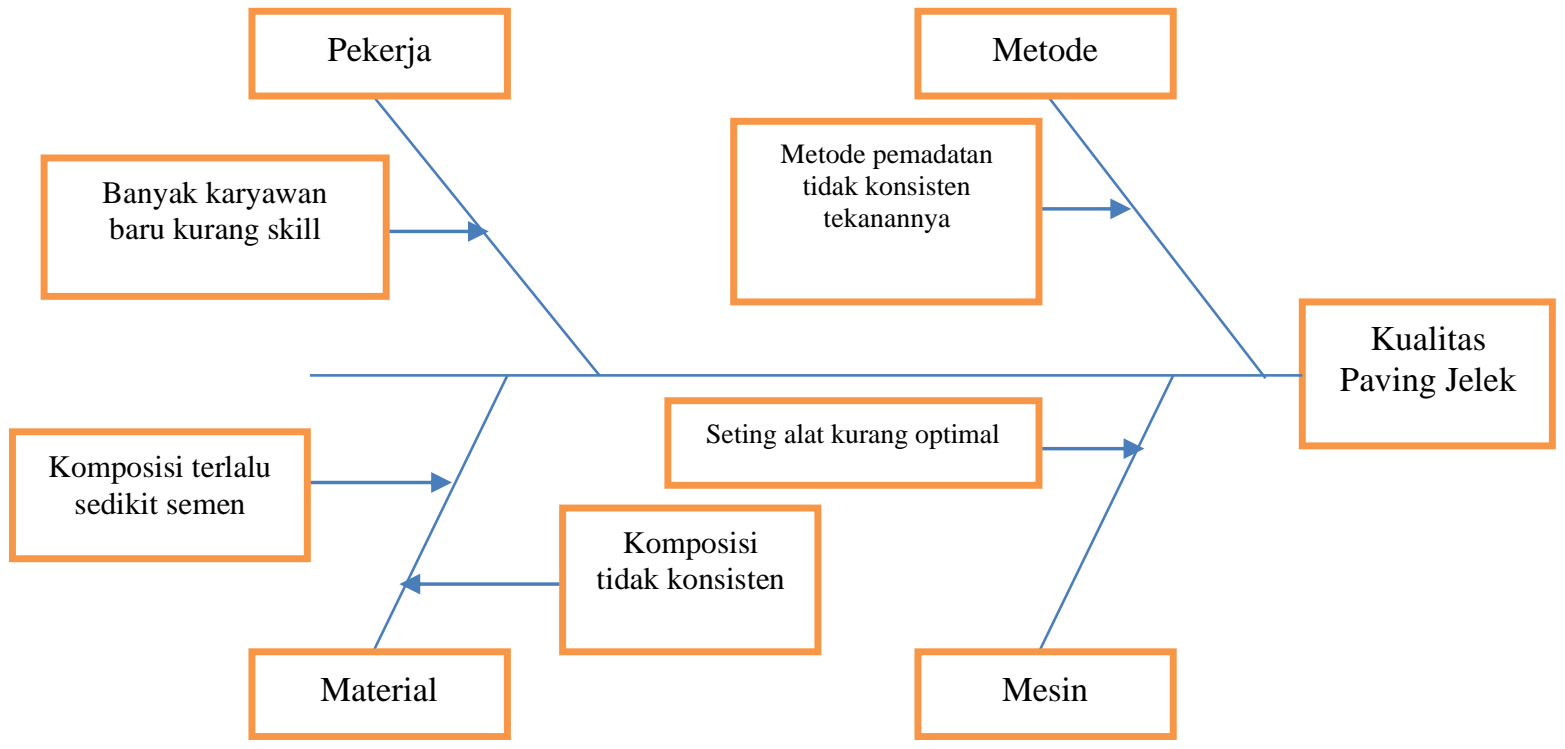

Gambar 3. Diagram Ishikawa Penyebab Kualitas Paving UD Rina Khatulistiwa Jelek

\section{Manajemen Pemasaran}

Penjualan paving ini dilakukan hanya melalui toko saja. Konsumen datang ke toko karena mendapat rekomendasi dari mulut ke mulut. Selama ini UMKM hanya mengandalkan toko saja untuk menarik minat konsumen. Peminatnya juga hanya dari lokal saja dari Kabupaten Pati. Lingkup penjualan hanya masih dalam lingkup yang kecil.' 


\section{Manajemen Keuangan}

Dalam bidang keuangan UMKM ini hanya menuliskan nota penjualan saja. Untuk biaya yang di keluarkan untuk membeli bahan, membayar upah karyawan belum memiliki pencatatan yang rapi. Kadang kala UMKM lupa untuk melakukan pencatatan. Sehingga ini yang menimbulkan keuangan tidak tertata dengan rapi. UMKM ini sebenarnya memiliki omzet yang lumayan tinggi, namun UMKM ini belum mampu untuk menyusun laporan keuangan. Dengan UMKM mampu menyusun laporan keuangan ini, diharapkan UMKM ini mampu meningkatkan kapasitas produksinya.

\section{Metode Pelaksanaan}

Kegiatan ini dilakukan melalui beberapa tahapan. Tahapan yang pertama adalah perencanaan program kegiatan, kedua pelaksanaan program, ketiga follow up kegiatan dan tahap terakhir tahap evaluasi kegiatan. Tahapan perencanaan ini meliputi kegiatan Forum Group Discussion (FGD) dengan mitra UD Rina Khatulistiwa. Dalam FGD ini, diperoleh tiga permasalahan yang sedang di hadapi oleh mitra. Tiga permasalahan yang dihadapi oleh mitra ini terdiri dari : a). bidang produksi, b). bidang pemasaran, c). bidang keuangan. Berdasarkan tiga permasalahan tersebut, di rencanakan akan dilakukan pendampingan atau pelatihan terkait dengan tiga permasalahan yang dihadapi oleh mitra. Pelatihan yang akan di laksanakan nanti akan di dampingi oleh pakar yang kompeten.

Tahap kedua adalah pelaksanaan pelatihan bagi mitra. Berikut ini rencana pelatihan yang akan di berikan kepada mitra :

Tabel. 3 Rencana Pelatihan

\begin{tabular}{lll}
\hline \multicolumn{1}{c}{ Permasalahan } & \multicolumn{1}{c}{ Materi } & \multicolumn{1}{c}{ Nara Sumber } \\
\hline Bidang Produksi & Perbaikan Kualitas Produk Paving Hidrolis & Rangga Primadasa, ST, MT \\
Bidang Pemasaran & Pemasaran Online Bagi UMKM & Nurul Rizka Arumsari, SE, MM \\
Bidang Keuangan & Proses Penyusunan Laporan Keuangan & Nanik Ermawati, SE, M.Si \\
\hline
\end{tabular}

Pelatihan bidang produksi ini diberikan kepada buruh yang bekerja di bagian produksi paving kurang lebih ada 10 orang buruh. Pelatihan bidang pemasaran dan bidang keuangan ini diberikan kepada karyawan toko UD Rina Khatulistiwa.

Tahap ketiga adalah follow up, yaitu kegiatan praktik di lapangan setelah memperoleh pelatihan dari nara sumber. Follow up pertama adalah bidang produksi yang ditujukan kepada buruh pembuat paving. Setelah memperoleh pelatihan bagaimana membuat adonan paving yang tidak mudah pecah, tahap selanjutnya adalah praktek di lapangan untuk mempraktekkan teori yang sudah diberikan nara sumber. Follow up yang kedua adalah bidang pemasaran, karyawan UD Rina Khatulistiwa di ajak praktek untuk membuat media pemasaran melalui instagram maupun melalui shopee. Follow up yang ketiga adalah bidang keuangan, mitra di bombing untuk langsung menyusun laporan keuangan berdasarkan nota belanja yang sudah di arsip oleh mitra.

Tahap akhir dari kegiatan ini adalah evaluasi kegiatan. Evaluasi kegiatan ini digunakan untuk menilai apakah kegiatan pelatihan yang sudah dilakukan kepada mitra ini mampu memberikan dampak yang besar bagi mitra. Evaluasi dilakukan dengan cara memberikan beberapa pertanyaan kepada mitra yang telah mengikuti pelatihan :

a. Bidang produksi : 1). Apakah pelatihan "Perbaikan Kualitas Produk Paving Hidrolis" mudah untuk dipahami? 2). Apakah pelatihan "Perbaikan Kualitas Produk Paving Hidrolis" sudah diaplikasikan dengan baik? 3). Apakah pelatihan "Perbaikan Kualitas Produk paving Hidrolis" mampu membuat produk paving yang kuat dan tidak mudah pecah? (Yumniati et al., 2019).

b. Bidang pemasaran : 1). Apakah pelatihan "Pemasaran Online Bagi UMKM" mudah untuk dipahami? 2). Apakah pelatihan "Pemasaran Online Bagi UMKM" sudah diaplikasikan oleh UMKM? 3). Apakah pelatihan "Pemasaran Online Bagi UMKM" mampu meningkatkan omzet mitra? (Yumniati et al., 2019)

c. Bidang keuangan : 1). Apakah pelatihan "Proses Penyusunan Laporan Keuangan" mudah dipahami oleh mitra? 2). Apakah pelatihan "Proses Penyusunan Laporan Keuangan" sudah di aplikasikan dalam usaha mitra? 3). Apakah pelatihan "Proses Penyusunan Laporan Keuangan" mampu mempermudah mitra untuk mengetahui perkembangan usahanya? (Yumniati et al., 2019)

Petunjuk pengisian kuesioner dengan mengisi jawaban ya dan tidak.

Metode pelaksanaan ini secara singkat dapat digambarkan sebagai berikut : 


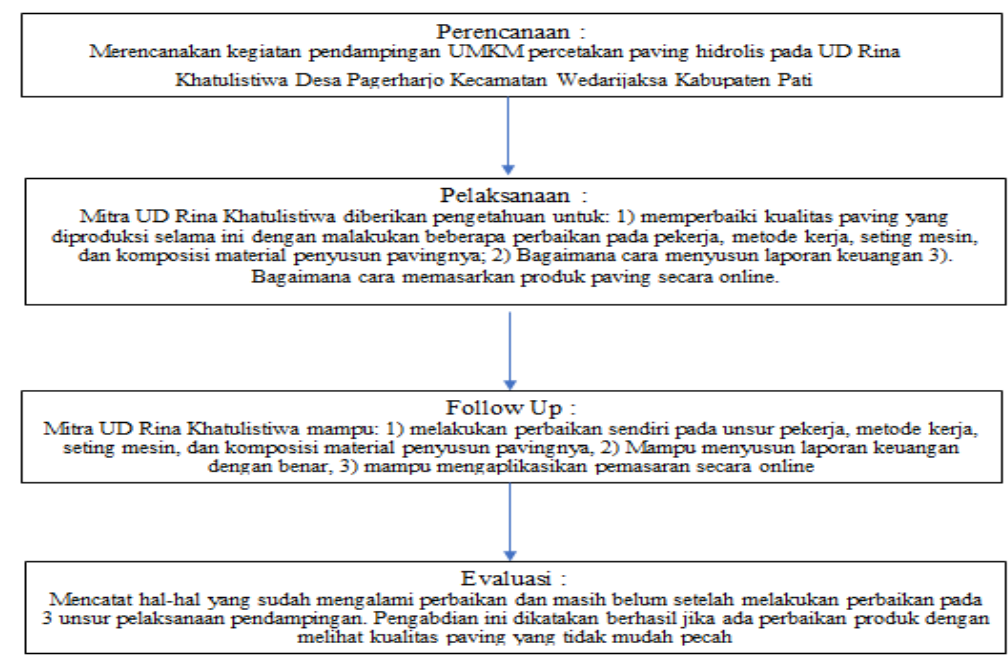

Gambar 4: Alur Realisasi

\section{Hasil Dan Pembahasan}

Pelaksanaan Kegiatan

Pelaksanaan kegiatan ini dilaksanakan pada tanggal 17 Februari 2020 sampai dengan tanggal 5 April 2020. Pelaksanaan kegiatan ini terdiri dari : pelaksanaan pelatihan, follow up dan evaluasi. Berikut ini rincian pelaksanaan kegiatan pelatihan yang telah dilakukan kepada mitra :

Tabel 4. Pelaksanaan Kegiatan Pelatihan

\begin{tabular}{|c|c|c|c|c|}
\hline Tanggal & Permasalahan & $\begin{array}{l}\text { Judul Pelatihan } \\
\end{array}$ & Peserta & Nara sumber \\
\hline $17 / 2 / 2020$ & Bidang Produksi & Perbaikan Kualitas Produk Paving Hidrolis & $\begin{array}{l}\text { Buruh pembuat } \\
\text { paving }\end{array}$ & $\begin{array}{l}\text { Rangga } \\
\text { Primadasa, ST, } \\
\text { MT }\end{array}$ \\
\hline $24 / 2 / 2020$ & $\begin{array}{l}\text { Bidang } \\
\text { Pemasaran }\end{array}$ & Pemasaran Online Bagi UMKM & $\begin{array}{l}\text { Karyawan } \\
\text { Toko UD Rina } \\
\text { Khatulistiwa }\end{array}$ & $\begin{array}{lr}\text { Nurul } & \text { Rizka } \\
\text { Arumsari, } & \text { SE, } \\
\text { MM } & \end{array}$ \\
\hline $2 / 3 / 2020$ & $\begin{array}{l}\text { Bidang } \\
\text { Keuangan }\end{array}$ & Proses Penyusunan Laporan Keuangan & $\begin{array}{l}\text { Karyawan } \\
\text { Toko UD Rina } \\
\text { Khatulistiwa }\end{array}$ & $\begin{array}{l}\text { Nanik Ermawati, } \\
\text { SE, M.Si }\end{array}$ \\
\hline
\end{tabular}

Pelaksanaan pelatihan perbaikan kualitas produk paving hidrolis ini di ikuti oleh sepuluh orang peserta pembuat paving. Mitra diberikan pelatihan bagaimana membuat adonan paving yang berkualitas, bagaimana teknik mengepres paving supaya paving tidak mudah pecah. Pelatihan pemasaran online dilaksanakan pada tanggal 24 Februari 2020 yang di ikuti oleh lima karyawan UD Rina Khatulistiwa. Pelatihan pemasaran ini memberikan wawasan mitra jenis-jenis pemasaran baik online maupun offline (Philip \& Armstrong, 2008). Pelatihan keuangan ini diikuti oleh lima orang karyawan UD Rina Khatulistiwa. Pelatihan ini memberikan materi bagaimana cara menyusun laporan keuangan bagi UMKM. Proses penyusunan laporan keuangan terdiri dari transaksi, jurnal, buku besar dan laporan keuangan (Bahri, 2016). Laporan keuangan terdiri dari laporan laba rugi, laporan perubahan ekuitas, laporan posisi keuangan (Dunia, 2013). Pelaksanaan pelatihan ini juga di lengkapi dengan modul pelatihan. Modul pelatihan ini terdiri dari : 1). Peningkatan kualitas paving hidrolis pada UR Rina Khatulistiwa, 2). Proses Penyusunan Laporan Keuangan pada UD Rina Khatulistiwa. Berikut ini modul pelatihan : 
PENINGKATAN KUALTAS PAVING HIDROLIS Pada UD Rina Khatulistiwa

Pecramatan Wedarijaksa

Kabupaten Pati

Nanik Ermawt

Nurul Rizka Arums

Rangga Primadasa, S.T., M.T.
PENINGKATAN KUALITAS PAVING HIDROLIS
PADA UD RINA KHATULISTIWA

DESA PAGERHARJO KECAMATAN WFDARIJAKS

KABUPATEN PAT

Nanik Ermawat, SE, MU.S.

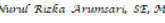

Rangga Primadiasa, s.T., M.T.

Program Pemberdayaan Masyarakat dan UMKM

Pengabdian Masyarakat Universitas Muria Kudus 2020

Gambar 5 : Modul Pelatihan
Proses Penyusunan Laporan

Keuangan pada Usaha Paving "UD RINA KHATULISTIWA”

DI SUSUN OLEH:

NANIK ERMAWATI, SE, M. S:

Tahap follow up dilaksanakan untuk melakukan perbaikan setelah mengikuti pelatihan yang telah di ikuti mitra. Follow up ini terdiri dari tiga bidang yaitu bidang produksi, bidang pemasaran dan bidang keuangan. Berikut ini follow up kegiatan :

Tabel 5. Follow Up Kegiatan Pelatihan

\begin{tabular}{ccl}
\hline Tanggal & Bidang Kegiatan & \multicolumn{1}{c}{ Kegiatan Follow Up } \\
\hline $10 / 3 / 2020$ & Bidang Produksi & $\begin{array}{l}\text { Perbaikan Kualitas Produk Paving Hidrolis : 1). Praktek di lapangan untuk } \\
\text { mempraktekkan teori yang sudah diberikan nara sumber, 2). Perbaikan } \\
\text { metode kerja, setting mesin, perbaikan komposisi penyusunan material } \\
\text { paving }\end{array}$ \\
& & $\begin{array}{l}\text { Pemasaran Online Bagi UMKM : Mitra mampu membuat media pemasaran } \\
\text { online melalui akun instagram }\end{array}$ \\
17/3/2020 & Bidang Pemasaran & $\begin{array}{l}\text { Proses Penyusunan Laporan Keuangan : Mitra di minta mempraktekkan } \\
\text { menyusun laporan keuangan yang sudah diajarkan dengan menggunakan } \\
\text { nota penjualan dan nota belanja yang sudah di arsip dengan baik }\end{array}$ \\
\hline
\end{tabular}

Berikut ini proses follow up atas kegiatan pelatihan :

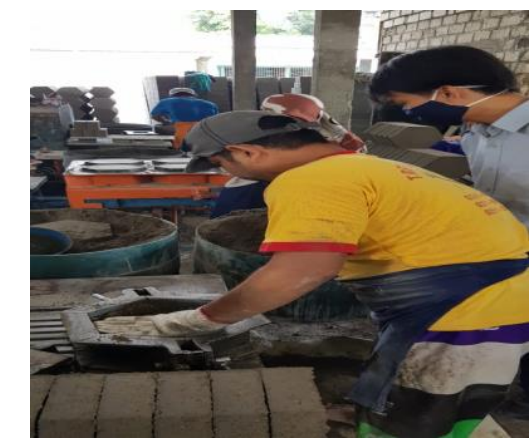

Gambar 6 : Follow Up Bidang Produksi
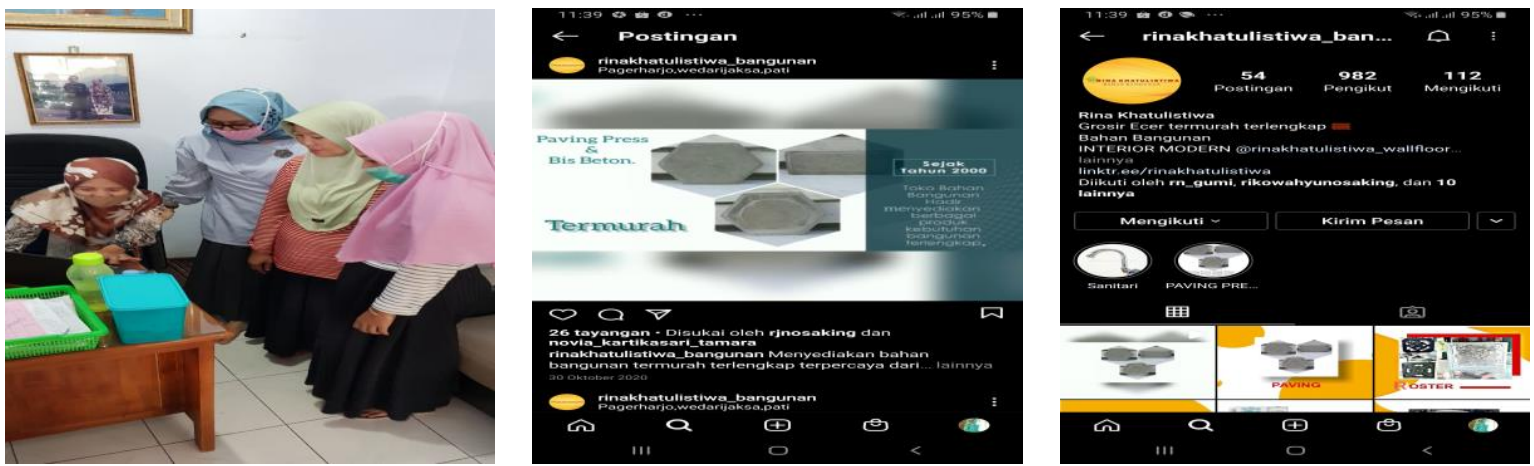

Gambar 7 : Follow Up Bidang Pemasaran 

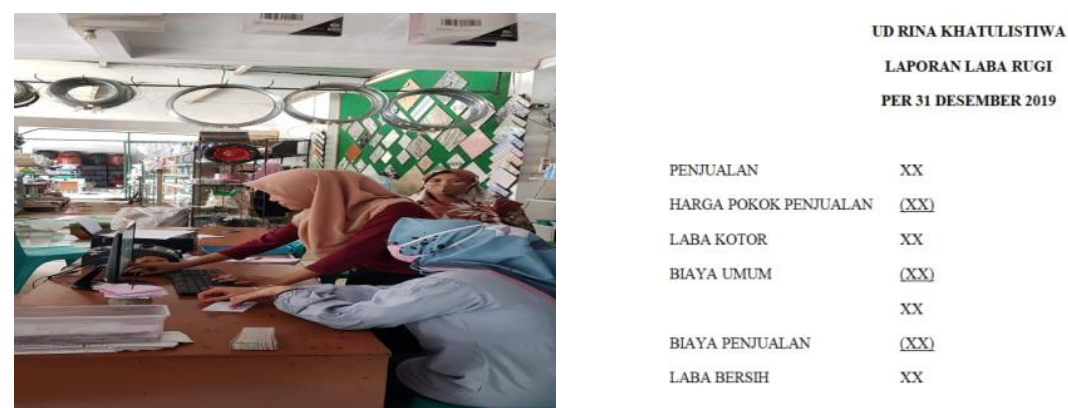

Gambar 8 : Follow Up Bidang Keuangan

Tahap terakhir adalah proses evaluasi kegiatan. Proses evaluasi kegiatan ini digunakan untuk menilai dampak dari adanya kegiatan pelatihan ini. Selain itu juga untuk menilai seberapa efektifkah pelatihan yang sudah diberikan kepada mitra. Evaluasi ini diperuntukkan untuk menilai perbaikan kualitas, perbaikan manajemen pemasaran maupun perbaikan keuangan. Untuk menilai perbaikan tersebut, mitra diminta untuk mengisi kuesioner evaluasi pelatihan untuk meningkatkan kualitas produk paving pada UD Rina Khatulistiwa. Dari hasil kuesioner yang diberikan diperoleh hasil sebagai berikut :

Tabel 6. Hasil Kuesioner

\begin{tabular}{|c|c|c|c|}
\hline Bidang & Pertanyaan & Ya & Tidak \\
\hline \multirow[t]{3}{*}{$\begin{array}{l}\text { Bidang } \\
\text { produksi }\end{array}$} & $\begin{array}{l}\text { 1). Apakah pelatihan "Perbaikan Kualitas Produk Paving Hidrolis" mudah } \\
\text { untuk dipahami? }\end{array}$ & $80 \%$ & $20 \%$ \\
\hline & $\begin{array}{l}\text { 2). Apakah pelatihan "Perbaikan Kualitas Produk Paving Hidrolis" sudah } \\
\text { diaplikasikan dengan baik? }\end{array}$ & $70 \%$ & $30 \%$ \\
\hline & $\begin{array}{l}\text { 3). Apakah pelatihan "Perbaikan Kualitas Produk paving Hidrolis" mampu } \\
\text { membuat produk paving yang kuat dan tidak mudah pecah? }\end{array}$ & $80 \%$ & $20 \%$ \\
\hline \multirow[t]{3}{*}{$\begin{array}{l}\text { Bidang } \\
\text { pemasaran }\end{array}$} & $\begin{array}{l}\text { 1). Apakah pelatihan "Pemasaran Online Bagi UMKM" mudah untuk } \\
\text { dipahami? }\end{array}$ & $75 \%$ & $25 \%$ \\
\hline & $\begin{array}{l}\text { 2). Apakah pelatihan "Pemasaran Online Bagi UMKM" sudah diaplikasikan } \\
\text { oleh UMKM? }\end{array}$ & $100 \%$ & $0 \%$ \\
\hline & $\begin{array}{l}\text { 3). Apakah pelatihan "Pemasaran Online Bagi UMKM" mampu meningkatkan } \\
\text { omzet mitra? }\end{array}$ & $75 \%$ & $25 \%$ \\
\hline \multirow[t]{3}{*}{$\begin{array}{l}\text { Bidang } \\
\text { keuangan }\end{array}$} & $\begin{array}{l}\text { 1). Apakah pelatihan "Proses Penyusunan Laporan Keuangan" mudah } \\
\text { dipahami oleh mitra? }\end{array}$ & $60 \%$ & $40 \%$ \\
\hline & $\begin{array}{l}\text { 2). Apakah pelatihan "Proses Penyusunan Laporan Keuangan" sudah di } \\
\text { aplikasikan dalam usaha mitra? }\end{array}$ & $60 \%$ & $40 \%$ \\
\hline & $\begin{array}{l}\text { 3). Apakah pelatihan "Proses Penyusunan Laporan Keuangan" mampu } \\
\text { mempermudah mitra untuk mengetahui perkembangan usahanya? }\end{array}$ & $60 \%$ & $40 \%$ \\
\hline
\end{tabular}

Berdasarkan hasil kuesioner di atas menunjukkan pelatihan bidang produksi dianggap berhasil dengan hasil kuesioner di atas 70\%. Pelatihan "Perbaikan Kualitas Produk Paving Hidrolis" sebanyak 80\% nya merasa mudah untuk dipahami. Tujuh puluh persen buruh pembuat paving sudah mengaplikasikan teknik pembuatan paving yang tidak mudah pecah. Buruh pembuat paving mampu menggunakan bahan material dengan baik, mampu menghasilkan produk paving dengan tekstur yang lebih rapi, mampu menghemat waktu dalam proses produksi. Hal ini di dukung dengan $80 \%$ buruh pembuat paving yang mampu membuat paving dengan kualitas kuat dan tidak mudah pecah.

Evaluasi bidang pemasaran menunjukkan hasil yang baik dengan nilai jawaban di atas $70 \%$. Sebanyak $75 \%$ yang mengikuti pelatihan "Pemasaran Online Bagi UMKM"merasa pelatihan yang telah diberikan cukup mudah dipahami. Mitra juga sudah mengaplikasikan pelatihan "Pemasaran Online Bagi UMKM" dengan membuat akun instagram @ @inakhatulistiwa_bangunan. Ini menunjukkan bahwa mitra sudah mengaplikasikan pelatihan pemasaran ini dengan baik. Pengikut instagram juga sudah mencapai 982 follower. 
Evaluasi bidang keuangan menunjukkan hasil yang kurang memuaskan karena hanya $60 \%$ mitra mampu menangkap pelatihan yang diberikan. Hal ini dikarenakan penyusunan laporan keuangan membutuhkan keahlian. Belajar penyusunan laporan keuangan memang membutuhkan waktu yang cukup panjang dan butuh pemahaman yang lebih dalam. Menurut Bahri (2016) penyusunan laporan keuangan yang terdiri dari laporan laba rugi, laporan perubahan ekuitas, laporan posisi keuangan ini membutuhkan tahapan yang panjang. Mitra memang sudah memulai menyusun laporan keuangan namun, banyak kendala yang harus dihadapinya karena ada banyak akun yang harus mereka pahami. Menurut (Bahri, 2016) laporan laba rugi ini harus memuat penjualan dan biaya-biaya yang dibutuhkan. Disinilah kesulitan mitra untuk mengelompokkan transaksi ke dalam akun akun laporan keuangan. Berikut ini adalah potret kebersamaan mitra dengan nara sumber :

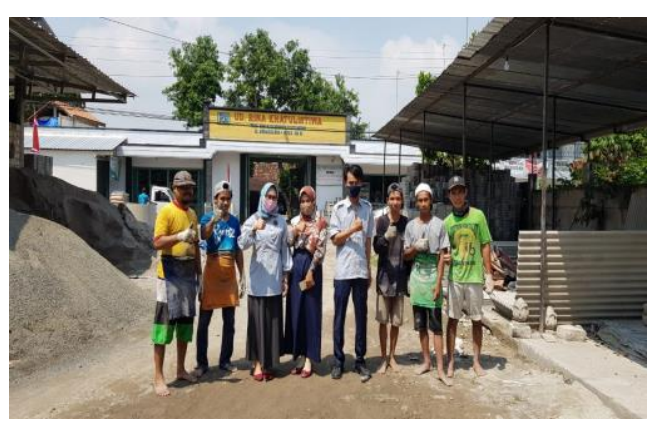

Gambar 9. Bersama dengan mitra

\section{Kesimpulan}

Tahapan yang sudah dilalui oleh buruh dan karyawan UD Rina Khatulistiwa melalui pemaparan materi dilanjutkan dengan pendampingan, praktek langsung ke lapangan dan tahap evaluasi yang terakhir, maka dapat disimpulkan bahwa :

a. Buruh pembuat paving yang bekerja pada UD Rina Khatulistiwa mampu memproduksi paving yang berkualitas dengan harapan dapat menaikkan penjualan

b. Bagian pemasaran UD Rina Khatulistiwa mampu membuat media online melalui instagram @ rinakhatulistiwa_bangunan dalam hal pemasaran produk paving.

c. Bagian keuangan UD Rina Khatulistiwa sudah mulai menyusun laporan keuangan yang terdiri dari laporan laba rugi, dimana sebelumnya bagian keuangan hanya mencatat keuangan perusahaan dalam bentuk penerimaan dan pengeluaran walaupun banyak kendala yang duhadapi.

Saran yang dapat diberikan untuk kemajuan UD Rina Khatulistiwa ini sebagai berikut :

a. Dalam bidang peningkatan kualitas produk paving : agar UD Rina Khatulistiwa menyiapkan wadah takaran untuk masing-masing bahan baku dengan diberi tanda batas untuk setiap sekali pencampuran bahan baku, sehingga takaran setiap bahan baku bisa konsisten setiap kali proses awal pencampuran dilakukan. Selain itu tingkat tekanan alat harus selalu konsisten untuk menjaga kualitas paving tetap sesuai standart yg diinginkan.

b. Saran di bidang pemasaran: sebaiknya UD Rina Khatulistiwa mendorong karyawan untuk memasarkan produknya dengan menggunakan SNS (Social Networking System). Dengam menggunakan SNS (Social Networking System) UD Rina Khatulistiwa dapat menghemat biasa promosi secara manual dalam memasarkan produknya. Masyarakat luas juga dapat melihat berbagai produk yang di pasarkan melalui SNS (Social Networking System).

c. Saran yang dapat diberikan dalam bidang keuangan ini, karyawan UD Rina Khatulistiwa mampu untuk menyusun laporan keuangan bulanan dan di arsip dengan rapi.

\section{Ucapan Terima Kasih}

Ucapaan Terima kasih dberikan kepada kepada :

a. Universitas Muria Kudus yang telah mendanai kegiatan pengabdian masyarakat ini sehingga kegiatan dapat berjalan dengan lancar. 
b. H Sayogo selaku pemilik UD Rina Khatulistiwa yang telah bersedia untuk menjadi mitra pengabdian kami

c. Seluruh karyawan UD Rina Khatulistiwa yang bersedia untuk mengikuti pelatihan yang kami selenggarakan.

\section{Daftar Pustaka}

Adibroto, F. (2014). Pengaruh Penambahan Berbagai Jenis Serat Pada Kuat Tekan Paving Block. Jurnal Rekayasa Sipil (JRS-Unand), 10(1), 1-11. https://doi.org/10.25077/jrs.10.1.1-11.2014

Bahri, S. (2016). Pengantar Akuntansi. Andi.

Corviniensis, A. T., Vii, E. T., Kiss, I., Stanojevic, D., \& Janjic, N. (2014). ANALYSIS OF TECHNOLOGICAL PROCESS OF CUTTING LOGS USING.

Dunia, F. (2013). Pengantar Akuntansi. Fakultas Ekonomi Universitas Indonesia.

Philip, K., \& Armstrong. (2008). Prinsip-Prinsip Pemasaran (Prenhallindo (ed.); 2nd ed.). Prenhallindo.

Sembiring, A. C., \& Saruksuk, J. J. (2018). Uji Kuat Tekan Dan Serapan Air Pada Paving Block dengan Bahan Pasir Kasar, Batu Kacang, dan Pasir Halus. JURITI PRIMA (Junal Ilmiah Teknik Industri Prima), 1(1). doi: https://doi.org/10.5281/zenodo.1207331

Yumniati, A., Setianingsih, S., \& Santoso, Y. D. (2019). Pelatihan Penyusunan Laporan Keuangan Bagi Entitas Mikro, Kecil, dan Menengah Bidang Usaha Dagang pada UMKM Binaan Pusat Inkubasi Bisnis Syariah Majelis Ulama Indonesia. Jurnal Pengabdian Masyarakat: Intervensi Komunitas, 1(1), 1-13. doi: https://doi.org/10.5281/zenodo.1207331 